Dražen Marić ${ }^{1}$
Veljko Marinković $^{2}$
Radenko Marić $^{3}$
Darko Dimitrovski $^{4}$
JEL: L84, M31, L83

DOI: $10.5937 /$ industrija1-8437

UDC: 338.488.2:640.412]:005.336.3

Original Scientific Paper

\title{
Analysis of Tangible and Intangible Hotel Service Quality Components
}

Article history:

Received: 5 June 2015

Sent for revision: 9 July 2015

Received in revised form: 17. November 2015

Accepted: 30. December 2015

Available online: 1 . April 2016

\begin{abstract}
The issue of service quality is one of the essential areas of marketing theory and practice, as high quality can lead to customer satisfaction and loyalty, i.e. successful business results. It is vital for any company, especially in services sector, to understand and grasp the consumers' expectations and perceptions pertaining to the broad range of factors affecting consumers' evaluation of services, their satisfaction and loyalty. Hospitality is a service sector where the significance of these elements grows exponentially. The aim of this study is to identify the significance of individual quality components in hospitality industry. The questionnaire used for gathering data comprised 19 tangible and 14 intangible attributes of service quality, which the respondents rated on a five-degree scale. The analysis also identified the factorial structure of the tangible and intangible elements of hotel service. The paper aims to contribute to the existing literature by pointing to the significance of tangible and intangible components of service quality. A very small number of studies conducted in hospitality and hotel management identify the sub-factors within these two dimensions of service quality. The paper also provides useful managerial implications. The obtained results help managers in hospitality to establish the service offers that consumers find the most important when choosing a given hotel.
\end{abstract}

Key words: service quality, tangibility, intangibility, consumers, hospitality sector, customers, satisfaction, etc.

\footnotetext{
${ }^{1}$ University of Novi Sad, Faculty of Economics in Subotica, Serbia,

2 University of Kragujevac, Faculty of Economics, Serbia

${ }^{3}$ University of Novi Sad, Faculty of Economics in Subotica, Serbia,

radenko.maric@yahoo.com

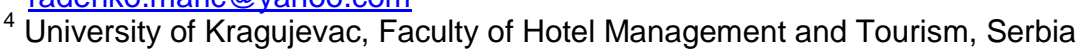


Marić D. et al.: Analysis of Tangible and Intangible Hotel Service Quality Components

\section{Analiza opipljivih i neopipljivih komponenti kvaliteta hotelskih usluga}

Apstrakt: Pitanje kvaliteta usluga jedno je od najvažnijih područja marketing teorije i prakse budući da visok kvalitet može voditi ka satisfakciji i lojalnosti potrošača, tj ka uspešnom poslovnom rezultatu preduzeća. Za svako preduzeće, naročito u usložnom sektoru, od vitalne je važnosti da razume $i$ spozna očekivanja $i$ percepcije potrošača vezana za kvalitet ponuđenih usluga, kao i da analizira široku paletu faktora koji utiču na potrošačku evaluaciju usluga, njihovu satisfakciju i lojalnost. Hotelijerstvo predstavlja uslužni sektor u kojem značaj ovih elemenata eksponencijalno raste. Cilj rada je identifikacija važnosti pojedinih komponenti kvaliteta usluga u hotelijerstvu. Upitnik putem kojeg su prikupljeni podaci sadržao je 19 opipljivih i 14 neopiljivih atributa kvaliteta usluge koje su ispitanici ocenjivali na petostepenoj skali. Analizom je identifikovana i faktorska struktura opipljivih i neopipljivih elemenata kvaliteta usluga hotela. Rad nastoji doprineti postojećoj literaturi ukazivanjem na značaj odvojenog ispitivanja opipljive i neopiljive komponente kvaliteta usluge. U veoma malom broju studija sprovedenih u hotelijerstvu, identifikovani su podfaktori u okviru pomenute dve dimenzije kvaliteta usluga. Rad pruža i korisne menadžerske implikacije. Dobijeni rezultati pomažu menadžerima u hetelijerstvu da utvrde atribute uslužne ponude koji su najvažniji potrošačima prilikom njihovog izbora određenog hotela.

Ključne reči: kvalitet usluga, opipljivost, neopipljivost, potrošači, hotelijerstvo, satisfakcija.

\section{Introduction}

Over the past few decades, tourist industry, notably hotel-based hospitality, is regarded as the key driver of growth and domination of service sector in national economies, both in developed and developing countries. The conditions of increasingly intensive competitive struggle on the market impose the imperative of construction, maintenance and enhancing customer relations on service organisations, so as to protect both their own and the interests of others stakeholders. Such competitive conditions and highly competitive business milieu result in service organisations finding it increasingly to differentiate themselves one from the other, which further results in a sparse customer base, especially of those regarded as loyal. Service organisations may find a response to thus set challenges in the 
delivery of superior-quality service. A company's business success - high profitability, level of sales and market share, are always based on customer loyalty, which is a result of a high level of their satisfaction, implying that their expectations regarding the service have been met and surpassed. In other words, superior service quality surpassing the consumers' expectations is the only pathway attaining business success on the competitive market (Zaharia et al, 2014).

Hospitality has long been viewed as a global industry whose services become a way of life for many individuals. In the recent years, the volume and needs for hotel service seem to be outgrowing the traditional hotel offer, imposing a question on the top management whether the quality and offer of services match the needs and desires of customers, and, even more importantly, whether they meet and surpass their expectations. For these reasons, modern hotel industry inevitably places a significant accent on service quality.

The demands of hotel guests and their expectations tend to change dynamically in the modern hotel industry. When asked to define service, most hotel guests (Mola, Jusoh, 2011) answer using commonplaces such as "getting what I want, when I want it, with a smile and respect". Despite being too generalised, thus worded expectations still send a clear message services imply, and customers demand, both tangible and intangible components. The survival of hotels in the existing competitive environment increasingly depends on the quality of service, with the only objective to achieve maximum possible satisfaction levels of hotel guests. Hotel guests' satisfaction becomes a key indicator of hotel business and an inevitable condition for achieving competitive advantage and high business performance. Identifying consumers' expectations and monitoring, measuring and managing these in terms of quality and satisfaction provides crucial information for business decision making.

Continuously providing superior service, hotels are able to build long-term relations with their clients and all other stakeholders affecting their functioning. In this context, service quality stands out as a significant factor of loyalty and sustainable development. Permanent measurement of service quality, satisfaction, consumer loyalty and creating service offer in accordance with their desires, the management follows the principles of corporate social responsibility. This article presents conducted empirical research aimed at identifying factors influencing the consumer's choice of a given hotel. Thus, the paper points to the significance of customer orientation in hospitality industry, for it is the continuous measurement o customers' perceptions and opinions on the significance of various components of quality service that helps the management to formulate and implement efficient business strategies that will contribute to creating sustainable competitive advantage. 
Marić D. et al.: Analysis of Tangible and Intangible Hotel Service Quality Components

\section{Literature review}

Applying marketing orientation implies orientation to consumers' needs and earning profit along with creating their satisfaction (Kotler, Armstrong, 1994). As a science, philosophy and concept, modern marketing took its shape and became institutionalised in the second half of the 20th century, and, as such, precisely defined its role in the society. The essence of modern marketing could be viewed in terms of: research, analysis, building, maintaining, and advancing relationships, between both companies and individuals with their stakeholders. Marketing is currently taken as the basic creed and a manner of general existence, not only in the sphere of economy and earning, but also as a highly popular aspect of the modern culture as a whole. 'Getting to know and serving consumers', and, lately, understanding them, is becoming a generally accepted principle of a company's operation and existence (Urban, 2005).

There is a growing number of not only marketing theoreticians, but also business leaders, who advocate a holistic and multidimensional view of customers, who are not merely buyers of products and services offered by the company on the market, but rather networked members of a large number of social groups, maintaining a large number of links and relationships, with a common denominator of functioning as stakeholders for the company (Daub, Erzeniger, 2005).

The contemporary business environment in the hotel industry at the global level demands consistency in providing high-quality services to clients. The share of costumer orientation within hospitality business is the key element leading to higher levels of client satisfaction and beneficial impact on the hotel's overall performance (Milovanović, 2014). It is essential for all hotel employees to understand the importance of customer orientation, especially the employees directly involved in the service provision process. Narver, Slater and Tietje (1998) note that customer orientation can result in gaining competitive advantage, for securing high quality provides service that is unique and hard to imitate. Customer orientation can also be viewed as one of the ways of obtaining important information on their preferences, so that recognising customers' needs and wishes will raise the perceived quality and value of hotel service. However, the problems of contemporary business operations in all industries, including hospitality, are caused by four factors that cannot be predicted with significant likelihood - the general state of economy, technological changes, competitor, and, most of all, customers (Gummesson, 2008).

The choice of a hotel is a function of client satisfaction and service and facility quality. Wuest, Tas and Emenheiser (1996) define the perception of hotel attributes as the degree to which hotel guests find various services and 
facilities important for achieving satisfaction with their stay in the hotel. Measuring hotel guest satisfaction is conducted with the aim of improving the quality of hotel services and improving the hospitality company's competitive advantages. In addition, satisfaction influences repeated visits and frequent stays, and the positive word-of-mouth communication (Maričić, 2011; KovačŽnideršić, Marić, Grubor, Salai, 2008). One of the greatest experts in the area of marketing services, Christian Gronroos (2004) points to the significant fact that consumers do not seek and services per se, but rather seek and expect the solution to their problems, which, for them, represents a value they are willing to pay for. In other words, whatever consumers purchase, they perceive it primarily as service, whether it is sometimes manifested as a demand for a lower price or demand for a familiar brand.

A large body of conducted research evidences that client satisfaction and service quality are prerequisites for creating loyalty (Cronin, Taylor, 1994). In fact, service quality is a prerequisite, whereas loyalty is the consequence of satisfaction (Dabholkar, Spherd, Thorpe, 2000). Getty and Thomson (1994) conducted research into the relationship between the quality of hotel accommodation and guest satisfaction, and the influence of these two variables on the guests' willingness to recommend the hotel to their friends and acquaintances. Results indicate that the guests' willingness to recommend the hotel serves the purpose of perception of satisfaction and quality of service of the hotel facilities Hueng, Huang and Wu (1996) established that brand loyalty in hospitality depends on the hotel's image. A study conducted by Kandampully and Suhartanto (2000) also confirms the significant impact of hotel image on guest loyalty. In order to create long-term profitability, many hotels have developed loyalty programmes as a constituent part of their marketing activities.

Fierce competition is the main characteristic of hospitality industry. An additional aggravating factor for hotels is the fact that the hotel guests are very well informed, remaining loyal only to hotels they perceive as leaders in continuous improvement of service quality. Such operating conditions impose themselves as condition sine qua non creating, delivery and maintaining hotel service quality, which places the guests at the heart of the service process itself. The overall conclusion is more than clear - enhancing service quality imposes itself as a prerequisite for survival and sustainable development of any service company. Some authors argue that service quality has already replaced pricing as the decisive factor in the clients' choice (Harrington \& Akehurst, 2000). Achieving competitiveness my means of pricing only does not yield adequate results in the long run, which is why an increasing number of hotels opt for achieving competitiveness by means enhancing service quality. Hotel management's learning about the perception of service quality by their clients enables assessment of performance and problems arising in the service provision process. The above stated arguments set a single 
imperative, i.e. that the hotel service quality placing the guest in the foreground must become a part of strategic business planning in hotel industry.

It is important to note that, despite the major invested research effort, both in quantitative and qualitative terms, into the attempt to shed light on the issue of service quality, marketing theory and practice still have not fully grasped all the mechanisms and factors affecting the interaction between the service provider and consumers, i.e. this interaction, the moment of truth to express it metaphorically, when the consumer perceives service quality is outside the service organisation's control. The service quality being the key element of achieving sustainable competitive advantage, especially in hotel industry, both the business and academic community consistently keep researching this area. Consumers view service as a range of attributes that can affect their purchase intention and perception of quality of the service itself (Marković, Raspor, 2010).

What decelerates the research into, and even more, providing, measuring and maintaining quality service is the very nature and characteristics of service. In their co-research into service quality, Parasuraman, Berry and Zeithaml $(1985,1988)$, established that service quality cannot be either conceived nor assessed by traditional product quality method, as services have three specific characteristics: intangibility, heterogeneousness and indivisibility. Gronroos (2004) points out that any service organisation must define and view service identically as consumers, i.e. that quality is only what consumers perceive it to be. The same author elaborates the issue of service quality along two avenues, i.e. two dimensions of quality - the technical (what was provided to the consumer) and the functional dimension (how it was provided to the consumer), which directly affect the consumer's quality perception and satisfaction levels. As regards the satisfaction of hotel service consumers, it is defined as the consumer's evaluation of the level of matching the perceived and experienced service on the one hand and their expectations on the other (AbuKhalifeh, Som, 2012). Buyers' expectations, as one of the integral elements of their satisfaction, can be perceived as normative - what the consumer thinks should happen based on his experience, or as prognostic what the consumers predicts will happen in interaction with the service provider.

SERVQUAL is suitable instrument for measuring the quality of service in hotels, although the criticism of its shortcomings (Cronin, Taylor, 1994) accelerated the emergence of new approaches such as SERVPERF (Cronin, Taylor, 1994) and Normed Quality models (Teas, 1993). Knutson, Stevens, Wullaert and Patton (1991) used SERVQUAL to create a specific instrument for accommodation facilities called LODGSERV comprising 26 items designed for measuring consumers' expectations related to service quality in hotels. 
The SERVQUAL scale is based on the gap model (Parasuraman et al., 1985), showing that the gap between consumers' expectations and their opinions on the real performance results in service quality perception. SERQUAL model contains five service quality dimensions: tangibility, reliability, responsibility, confidence and empathy. Tangibility as a dimension includes physical objects, equipment, equipment, the staff's appearance and users' presence. The tangible aspect of the service is one of the rare dimensions that the potential users know and evaluate before the service itself. Reliability refers to the ability to render the service reliably and accurately, in accordance with promises made in promotional activities. High level of service consistency is decisive for reliability. Responsibility refers to the hotel management's eagerness to resolve hotel clients' problems rapidly and efficiently. Reliability is provided through employees' courtesy and knowledge, conveying their confidence and self-confidence to client Empathy encompasses understanding the clients' needs by means of individual approach (Juwaherr, 2004).

There has been a considerable amount of debate regarding what kind of expectations the real experiences of a given service should be compared to. In the original SERVQUAL instrument, customers were asked what they expected from the service they had consumed, so the expectations and experiences measurements related to the same service. The measurement method was changed later, so that customers were asked what they expected from an excellent or ideal service in the same category as the one they had consumed. The original Perceived Service Quality model from which the expectations/experiences comparison originates in service quality contexts was developed to help managers and researches understand how customers perceive features of a given service. Hence, the expectations concept in that model is quite clearly related to the same service that is also experienced.

However, independent of what one wants to know about a given service, different kinds of expectations could be measured. If one wants to assess how good a given service is considered to be compared to the best in its category, expectations of an ideal service should be measured. On the other hand, if one wants to find out how customers perceive the quality of a given service, both expectations and experiences regarding this particular service should be measured.

Most hotel products take on the form of tangible and intangible attributes. The tangible and intangible attributes are highly intertwined, and thus make a significant impact on the assessment of quality by the guests (Alzaid, Soliman, 2002). And yet, Bowen (1990) claims that the significance of intangibility is overestimated. Depending on the need, hospitality industry can use a holistic approach to evaluate the hotel product, or the hotel product may be viewed through its components, which can be divisible and measurable in 
compliance with the characteristics of tangibility and intangibility. The basis of the hotel offer is the accommodation facility, enriched with other tangible and intangible amenities.

The terms 'tangibility' or 'physical quality' usually refers to elements of services, such as the appearance, equipment, staff, advertising material and other physical characteristics used for rendering services. Parasuraman et al. (1988) use the term 'tangibility' in the SERQUAL model as one of the dimensions in service quality assessment. Tangibility in hotel business refers to the external appearance of hotel facilities and their accommodation and restaurant facilities. The tangible elements of a hotel product can be assessed, measured and submitted to certain standards. Johnston (1995) classifies tangibility to cleanliness or neat appearance of the tangible components and the physical comfort of the environment where services are provided. Albayrak, Caber and Aksoy (2010) argue that the tangible elements of hotel products are more influential on the overall satisfaction, as they can be modified or renewed more easily in comparison with the intangible. Oberoi and Hales in their study published in 1990 also highlight the importance of tangibility for hotel business Joes and Lockwood (2004) propose that hotels should devote particular attention to tangible elements in their own operation so as to achieve higher client satisfaction.

The SERVQUAL scale should be applied carefully, and the determinants and attributes of the instruments should always be reassessed in any situation before the instrument is used. Aswell as markets and cultural environments, service are different, so it may be necessary to add new aspects of the service to be studied to the original set of determinants and attributes, and sometimes to exclude some from measurement instrument used.

Intangibility is one of the key characteristics of services. (Wolak, Kalafatis, Harris, 1998). Johnston (1995) argues that the intangible aspects of the staffclient relationship have a significant effect, both positive and negative, on quality service. Bebko (2000) proposes that the significance of tangible components is lowest for services with the lowest share of tangibility, and highest for services with the highest share tangibility. Shostack (1982) proposed a molecular model, among others, for hotel companies as well. Service quality in hotel business has both a tangible and intangible basis, so that the hotel product is a mixture of elements not necessarily of the same type (Jones, Lockwood, 2004). The molecular model can be changed successfully in the case of a hotel product, given that it comprises a range of separate, but mutually linked elements, such hotel and room design, food and drink supply, employees' service, the overall ambience and atmosphere.

An overview of literature shows that hotel guests most frequently tend to consider the following attributes when making a decision on the choice of hotel: cleanliness, location, price, safety, quality of service and reputation of 
the hotel itself or the hotel itself. Atkinson (1988) found that the cleanliness of accommodation, security and helpful staff are hotels' most important attributes. Rivers, Toh and Alou (1991) point out that the members of patrons programme are most influenced by the convenience of location and overall service.

\section{Research methodology}

The conducted research had two basic objectives: (1) to identify the importance of individual components of the hotel's service offer, and (2) determining the factorial structure of tangible and intangible elements of service quality. In this context, the questionnaire used for gathering data encompassed 33 attributes (19 tangible and 14 intangible, whose relevance was assessed by the respondents on a five-point Likert scale $(1=$ absolutely irrelevant attribute; $5=$ absolutely relevant attribute). The respondents, therefore, did not assess a specific type of hotel, but pointed to what extent they find individual attributes of the hotel's service offer relevant to their choice of a certain hotel they would spend their holiday in. The choice of questions was made based on the overview of relevant literature (Choi, Chu, 2000; Juwaheer, 2004; Mohsin. Lockyer, 2010; Parasuraman et al., 1988). Before designing the final version, the questionnaire was pre-tested on a sample of 20 respondents. The preliminary analysis showed that the questions were logically conceived and clear to the respondents.

The research was conducted on the territory of Kragujevac, one of the five largest cities in Serbia. The primary data was gathered through personal interviews with 220 respondents who agreed to participate in the research. For the purpose of our study, a convenience sample was used, as a very popular and frequently applied type of questionnaire in marketing research (Bettencourt, 1997; Widing, Sheth, Pulendran, Mittal, Newman, 2003). Respondents who agreed to participate in the questionnaire were able to take the questionnaires home and fill them in there, thus getting an opportunity to contemplate the questions in the questionnaire at leisure. The respondents left their mobile phone numbers to the interviewers. Three days later, the interviewers contacted the respondents to collect the filled in questionnaires. Viewed by the gender structure, women accounted for $54.5 \%$, and men for $45 \%$ of the sample. Out of the five age categories, the largest number of respondents (36.4\%) was aged 26-35, followed by respondents aged 36-45. Mature respondents, aged over 45 , are the least represented in the sample. A justification for their somewhat lower representation can be found in the fact that these respondents travel less in comparison with members of younger generations. The majority of respondents are college educated $(47.7 \%)$. $32.7 \%$ have completed secondary education, whereas $19.5 \%$ of them have 
Marić D. et al.: Analysis of Tangible and Intangible Hotel Service Quality Components

completed higher education. In addition to the listed demographic characteristics, the sample was composed so as to include respondents from both urban and suburban communities. Table 1 provides a detailed presentation of the sample structure.

Table 1. Sample structure $(n=220)$

\begin{tabular}{|l|c|c|}
\hline Demographic data & $\begin{array}{c}\text { Number of } \\
\text { respondents }\end{array}$ & $\%$ \\
\hline Gender & & 54.5 \\
\hline female & 120 & 45.5 \\
\hline male & 100 & 22.3 \\
\hline Age & & 36.4 \\
\hline $18-25$ & 49 & 22.3 \\
\hline $26-35$ & 80 & 13.6 \\
\hline $36-45$ & 49 & 5.5 \\
\hline $46-55$ & 30 & \\
\hline over 55 & 12 & 32.7 \\
\hline Education level & & 19.5 \\
\hline secondary & 72 & 47.7 \\
\hline college & 43 & \\
\hline university & 105 & 51.4 \\
\hline Marital status & & 48.6 \\
\hline married & 113 & 107 \\
\hline single & & \\
\hline
\end{tabular}

Source: author's calculation

Statistical analysis of the data was implemented in the Statistical Package for Social Sciences-SPSS 20. The usual descriptive statistical measures (arithmetical means and standard deviation) were used for establishing the relevance and homogeneity of respondents' opinions. Independent samples $t$ test was used for identifying statements with statistically significant differences in the assessment by males and females, and married and single respondents. Explorative factor analysis was used for identifying the factorial structure of hotel service quality. More specifically, two separate factorial analyses were conducted, one on tangible and the other on the intangible attributes of hotel operation. Before applying the factorial analysis, KaiserMeyer-Olkin (KMO) and Bartlett's test of sphericity were used for establishing whether the data were suitable for conducting factorial analysis. 
Marić D. et al.: Analysis of Tangible and Intangible Hotel Service Quality Components

\section{Result and Discussion}

In the first step of the analysis, the relevance of each of the 33 service quality attributes was established based on respondents' perceptions. Generally, respondents found intangible elements more important (Table 2).

Table 2. Results of descriptive statistical analysis

\begin{tabular}{|c|c|c|}
\hline Statement & $\begin{array}{l}\text { Arithmetic } \\
\text { mean }\end{array}$ & $\begin{array}{l}\text { Standard } \\
\text { deviation }\end{array}$ \\
\hline The external appearance of the hotel is modern. & 3.6591 & 1.09259 \\
\hline The hotel is excellently located. & 4.0909 & 1.03849 \\
\hline The hotel has top-of-the-range equipped reception desks. & 3.4545 & .93278 \\
\hline The hotel has visually appealing brochure. & 3.0045 & 1.20311 \\
\hline The hotel has a well-designed lobby. & 3.9091 & .86056 \\
\hline The hotel has clean rooms. & 4.8955 & .38579 \\
\hline The hotel has spacious rooms. & 4.0136 & 1.02248 \\
\hline The hotel room has a mini bar. & 3.2727 & 1.27433 \\
\hline The hotel has an appealing restaurant and bar & 4.0409 & 1.04386 \\
\hline The beds, pillows and bedding. & 4.7682 & .55385 \\
\hline The hotel rooms have comfortable bathrooms. & 4.6864 & .57877 \\
\hline The hotel has a pool. & 3.7045 & 1.18166 \\
\hline The hotel has a sauna. & 3,1136 & 1,33475 \\
\hline The hotel has sports facilities. & 3,5273 & 1,14445 \\
\hline Business lounges are always at guests' disposal. & 3,0455 & 1,26337 \\
\hline The hotel regularly maintains the hotel lawn and turf. & 3,9364 & ,92925 \\
\hline The hotel room has a TV set. & 4,2136 & ,78502 \\
\hline $\begin{array}{l}\text { The seating arrangement in the restaurant and bars is } \\
\text { good. }\end{array}$ & 3,4955 & 1,12464 \\
\hline The hotel's food and drinks are high quality & 4,4227 & ,83225 \\
\hline $\begin{array}{l}\text { Any promises made to guests are met within the agreed } \\
\text { deadline. }\end{array}$ & 4.8000 & .49287 \\
\hline $\begin{array}{l}\text { Hotel staff invest sincere effort to solve the guests' } \\
\text { problems' }\end{array}$ & 4.6636 & .58563 \\
\hline Hotel bills are flawless & 4.5727 & .89605 \\
\hline The hotel always provides service like the first time. & 4.6136 & .73453 \\
\hline $\begin{array}{l}\text { The hotel staff provide guests with all required } \\
\text { information. }\end{array}$ & 4.5409 & .63617 \\
\hline The staff provide fast and immediate service. & 4.6182 & .60412 \\
\hline The staff are willing to help the guests at any moment. & 4.6045 & .59907 \\
\hline The staff's behaviour is reassuring. & 4.4566 & .67843 \\
\hline The hotel staff is courteous to the guests. & 4.6727 & .59078 \\
\hline The staff devote adequate attention to each guest. & 3.9500 & .86655 \\
\hline $\begin{array}{l}\text { The hotel staff appear to give priority to what is best for } \\
\text { the guests. }\end{array}$ & 4.5909 & .63094 \\
\hline The hotel staff understand the guests' specific needs. & 4.0182 & .99755 \\
\hline Check-in and check-out are efficient. & 4.5682 & .61924 \\
\hline The hotel provides full security for its guests. & 4.8091 & .48720 \\
\hline
\end{tabular}

Source: author's calculation 
A single intangible attribute ('The staff devotes adequate personal attention to each guest') received a grade lower than 4 . On the other hand, in the customers' opinion, as many as 11 tangible attributes are significant below grade 3 . The following statements received the highest grades from the respondents: 'The hotel rooms are clean'; 'The hotel provides full security for its guests'; 'All promises made to guests are fulfilled within the agreed deadline; 'Beds, pillows and bedding are comfortable'; 'Hotel rooms have comfortable bathrooms'; 'Hotel staff invest sincere effort to solve the guests' problems'; 'The hotel staff are courteous to guests'. As regards intangible attributes, when choosing a hotel to stay in, what respondents obviously find the most important is trust they can have in the staff, accuracy of service, and the staff's willingness to help guests at all times. Although a number of tangible elements were not found highly important, the guests ascribe special relevance to the cleanliness and comfort of rooms and bathrooms. The highest graded statements are also characterised by low values of standard deviations, based on which it can be concluded that a vast majority of respondents have identical opinions on their relevance.

Statements graded by customers as the least relevant are: 'The hotel has visually appealing publicity brochures'; 'The hotel has sports facilities'; 'The hotel's food and drinks are high quality'; 'The hotel room has a mini bar'. All of these four statements are tangible by character. The highest differences in the respondents' opinions are certainly based on these statements, as confirmed by the high values of standard deviations. Not even the reception desk facilities are so important to customers (average grade 3.45). The guests obviously do not attribute high relevance to some additional services of the hotel, such as mini bars in rooms or sports facilities. Another interesting research finding is that guests do not find it so important for food and drinks at the hotel to be of high quality. The guests did not turn out to be too demanding in terms of food. However, the study may have yielded different results if the sample had included only respondents staying in luxury hotels.

In addition to establishing the relevance of attribute at the total sample level, we also established whether differences in respondents from different segments show differences in opinions. Table 3 lists the statements where responses indicated statistically significant differences in the opinions of men and women. Results reveal that the differences in opinions of respondents from these two segments mostly differ when tangible attributes are concerned. In this context, women, unlike men, pay more attention to the hotel's appearance, arrangement and design of the reception desk, the lobby and brochures. On the other sports facilities, as an attribute of the hotel's service offer, are more important to men than women. In addition to gender, marital status was also viewed as a criterion for respondent segmentation. The results of independent samples t test display generally similar opinions of married and single respondents. Still, in this case, differences appeared 
Marić D. et al.: Analysis of Tangible and Intangible Hotel Service Quality Components

mostly in intangible attributes, that is to say, out of the five statements where statistically significant differences were found, as many as for are classified as intangible elements of service quality. Results from Table 4 indicate that married respondents pay more attention to intangible attributes, such as fulfilling promises made to guests, efforts to resolve guests' problems, fast and immediate service, and check-out and check-in efficiency.

Table 3. Statements that yielded statistically significant differences between males and females

\begin{tabular}{|l|c|c|c|}
\hline Statements & $\begin{array}{c}\text { Males } \\
\text { Mean (SD) }\end{array}$ & $\begin{array}{c}\text { Females } \\
\text { Mean (SD) }\end{array}$ & t statistic \\
\hline $\begin{array}{l}\text { The outside appearance of the hotel is } \\
\text { up-to-date. }\end{array}$ & $3.44(1.09)$ & $3.84(1.06)$ & $-2.76^{* * *}$ \\
\hline $\begin{array}{l}\text { The hotel has contemporarily equipped } \\
\text { reception desk. }\end{array}$ & $3.25(0.87)$ & $3.62(0.95)$ & $-3.02^{* * *}$ \\
\hline $\begin{array}{l}\text { The hotel's brochures are visually } \\
\text { appealing. }\end{array}$ & $2.69(1.12)$ & $3.27(1.21)$ & $-3.64^{* * *}$ \\
\hline $\begin{array}{l}\text { The hotel's lobby is attractively } \\
\text { furnished }\end{array}$ & $3.77(0.81)$ & $4.02(0.88)$ & $-2.208^{* *}$ \\
\hline The hotel has sports facilities. & $3.68(1.19)$ & $3.40(1.09)$ & $1.816^{*}$ \\
\hline $\begin{array}{l}\text { The hotel staff provide guests with all } \\
\text { required information. }\end{array}$ & $4.46(0.66)$ & $4.61(0.61)$ & $-1.73^{*}$ \\
\hline $\begin{array}{l}\text { Notes: Significant at the 0.01 level }\left(^{* * *}\right) ; \text { Significant at the } 0.05 \text { level }\left(^{* *}\right) \text {; Significant at the } \\
\left.0.1 \text { level }{ }^{*}\right)\end{array}$ \\
\hline
\end{tabular}

Source: author's calculation

Results from Table 4 indicate that married respondents pay more attention to intangible attributes, such as fulfilling promises made to guests, efforts to resolve guests' problems, fast and immediate service, and check-out and check-in efficiency.

Table 4. Statements that yielded statistically significant differences among married and not married respondents

\begin{tabular}{|l|c|c|c|}
\hline \multicolumn{1}{|c|}{ Statements } & $\begin{array}{c}\text { Married } \\
\text { Mean (SD) }\end{array}$ & $\begin{array}{c}\text { Not married } \\
\text { Mean (SD) }\end{array}$ & t statistic \\
\hline The hotel has spacious rooms & $3.86(1.12)$ & $4.18(0.88)$ & $-2.35^{* *}$ \\
\hline $\begin{array}{l}\text { Any promises made to guests are } \\
\text { met within the agreed deadline. }\end{array}$ & $4.86(0.44)$ & $4,74(0.54)$ & $1.82^{*}$ \\
\hline $\begin{array}{l}\text { The hotel staff invest sincere effort } \\
\text { to solve the guests' problems. }\end{array}$ & $4.78(0.46)$ & $4.54(0.68)$ & $3.05^{* *}$ \\
\hline $\begin{array}{l}\text { The staff provide fast and immediate } \\
\text { service. }\end{array}$ & $4.73(0.52)$ & $4.49(0.66)$ & $2.99^{* * *}$ \\
\hline Check-in and check-out are efficient. & $4.70(0.48)$ & $4.43(0.71)$ & $3.29^{* * *}$ \\
\hline $\begin{array}{l}\text { Notes: Significant at the 0.01 level }\left({ }^{* *}\right) ; \text { Significant at the 0.05 level }\left(^{* *}\right) ; \text { Significant at the } \\
0.1 \text { level (*) }\end{array}$ \\
Source: author's calculation
\end{tabular}


Marić D. et al.: Analysis of Tangible and Intangible Hotel Service Quality Components

Table 5. The factorial structure of the tangible service quality elements

\begin{tabular}{|l|l|l|l|l|l|l|}
\hline Factors & $\mathbf{1}$ & $\mathbf{2}$ & $\mathbf{3}$ & $\mathbf{4}$ & $\mathbf{5}$ & $\mathbf{6}$ \\
\hline $\begin{array}{l}\text { Factor 1: Appearance and } \\
\text { facilities }\end{array}$ & & & & & & \\
\hline $\begin{array}{l}\text { The hotel has visually appealing } \\
\text { publicity brochures }\end{array}$ & .713 & & & & & \\
\hline $\begin{array}{l}\text { The hotel has top-of-the-range } \\
\text { equipped reception desks }\end{array}$ & .708 & & & & & \\
\hline The hotel is excellently located & .706 & & & & & \\
\hline $\begin{array}{l}\text { The external appearance of the } \\
\text { hotel is modern }\end{array}$ & .654 & & & & & \\
\hline $\begin{array}{l}\text { The hotel has a well-designed } \\
\text { lobby }\end{array}$ & .565 & & & & & \\
\hline $\begin{array}{l}\text { Factor 2: Sports and recreational } \\
\text { facilities }\end{array}$ & & & & & & \\
\hline $\begin{array}{l}\text { The hotel regularly maintains the } \\
\text { hotel lawn and turf }\end{array}$ & & .777 & & & & \\
\hline The hotel has sports facilities & & .612 & & & & \\
\hline Factor 3: Restaurants and bars & & & & & & \\
\hline $\begin{array}{l}\text { The hotel has an appealing } \\
\text { restaurant and bar }\end{array}$ & & & .707 & & & \\
\hline $\begin{array}{l}\text { The hotel's food and drinks are } \\
\text { high quality }\end{array}$ & & & .655 & & & \\
\hline $\begin{array}{l}\text { The seating arrangement in the } \\
\text { restaurant and bars is good }\end{array}$ & & & .529 & & & \\
\hline $\begin{array}{l}\text { Factor 4: Cleanliness and } \\
\text { comfort of rooms }\end{array}$ & & & & & & \\
\hline The hotel rooms are clean & & & & & \\
\hline $\begin{array}{l}\text { Beds, pillows and bedding are } \\
\text { comfortable }\end{array}$ & & & & & & \\
\hline $\begin{array}{l}\text { Factor 5: Swimming pool and } \\
\text { sauna }\end{array}$ & & & & & \\
\hline The hotel has a swimming pool & & & & & \\
\hline The hotel has a sauna & & & & & \\
\hline $\begin{array}{l}\text { Factor 6: Room and bathroom } \\
\text { size }\end{array}$ & & & & & \\
\hline The hotel has spacious rooms & & & & & \\
\hline $\begin{array}{l}\text { Hotel rooms have comfortable } \\
\text { bathrooms }\end{array}$ & & & & & \\
\hline Eigenvalue & & & & & \\
\hline $\begin{array}{l}\text { Percentage of variance accounted } \\
\text { for }\end{array}$ & 13.462 & 10.761 & & \\
\hline
\end{tabular}

Source: author's calculation

Having established the relevance attributes, the study identified the subfactors of tangible and intangible service quality dimensions. Two factor analyses were conducted. The first factor analysis was aimed at establishing the factorial structure of 19 tangible attributes of the hotel's service offer. In accordance with proposals provided by Hair, Anderson, Tatham and Black (1998), when conducting factor analysis, it is necessary to follow the rule that 
the minimum sample size must include five respondents per statements. As regards the conducted study, even if we had completed the factor analysis with all 33 attributes, the minimum required sample size would have been 165 respondents. Given that our sample included 220 respondents, this sample size can be deemed as appropriate for conducting factor analysis. The analysis of the main component was used as a method of factor analysis in the research. Varimax rotation was applied for interpreting factors, as a poplar rotation method in the case of reducing a larger number of statements to a smaller number of factors.

As seen in Table 5, factor analysis grouped tangible attributes around six newly formed factors, as follows: (1) the hotel's appearance and furnishings; (2) sports and recreational facilities; (3) restaurants and bars; (4) cleanliness and comfort of rooms; (5) swimming pool and sauna; and (6) size of rooms and bathrooms. Accordingly, three statements ('The hotel room has a mini bar'; 'Business lounges are always at guests' disposal' and 'The hotel room has a TV set' were excluded from further analysis, as their factor weights were lower than 0.5 (Hair et al., 1998). The values of the KMO test (KMO = $0.736>0.5)$ and Bartlett's test $(p=0.00<0.05)$ confirmed the justifiability of applying factor analysis. The first factor accounts for the highest percentage of variance in comparison with other factors (13.462\%). This factor included statements regarding location, outside appearance and design of the reception desk and the lobby. The second and the fifth factor encompass the elements of the additional contents offered by the hotels (sports facilities, walking paths, swimming pool and sauna). The fourth and the sixth factor gathered a group of statements related to the quality of rooms, where the fourth factor pertains to cleanliness and comfort, whereas the sixth factor refers to the size of the rooms. Finally, the fifth factor joins statements about quality, and design of the hotel restaurant and bars. All six factors together account for $61.624 \%$ of the total variance.

The second factor analysis that we conducted in the research was aimed at grouping 14 intangible attributes into a smaller number of latent factors. At the very start, we excluded four statements whose factor weights were under 0.5: 'Check-in and check-out are efficient'; 'The hotel staff provide guests with all required information'; 'The staff are willing to help the guests at any moment'; and 'The hotel staff appear to give priority to what is best for the guests'. In the case of intangible attributes as well, the values of KMO and Bartlett's test showed that the data were appropriate for the implementation of factor analysis. The value of the $\mathrm{KMO}$ index is higher than the required threshold of $0.5(\mathrm{KMO}=0.829)$, whereas the value $\mathrm{f}$ Bartlett's test is significant $(p=0.00)$. Three new factors were formed in the final step of the analysis: (1) staff's helpfulness; (2) personal attention; and (3) accuracy of service (Table 6). 
Marić D. et al.: Analysis of Tangible and Intangible Hotel Service Quality Components

Table 6. The factorial structure of the tangible service quality elements

\begin{tabular}{|l|c|c|c|}
\hline Factors & $\mathbf{1}$ & $\mathbf{2}$ & $\mathbf{3}$ \\
\hline Factor 1: Staff's helpfulness & & & \\
\hline The hotel provides full security for its guests & .789 & & \\
\hline $\begin{array}{l}\text { All promises made to guests are fulfilled within the } \\
\text { agreed deadline }\end{array}$ & .764 & & \\
\hline $\begin{array}{l}\text { The hotel staff invest sincere effort to solve the } \\
\text { guests' problems }\end{array}$ & .748 & & \\
\hline The staff provide fast and immediate service & .707 & & \\
\hline The hotel staff are courteous to guests & .645 & & \\
\hline The staff's behaviour is reassuring & .579 & & \\
\hline Factor 2: Personal attention & & & \\
\hline $\begin{array}{l}\text { The hotel staff understand the guests' specific } \\
\text { needs }\end{array}$ & & .831 & \\
\hline $\begin{array}{l}\text { The hotel staff devotes adequate attention to each } \\
\text { guest }\end{array}$ & & .760 & \\
\hline Factor 3: Accuracy of service & & & .862 \\
\hline Hotel bills are flawless & & & .853 \\
\hline The hotel always provides service like the first time & 3.966 & 2.127 & 1.959 \\
\hline Eigenvalue & 28.328 & 15.190 & 13.996 \\
\hline Percentage of variance accounted for & &
\end{tabular}

Source: author's calculation

The given factors account for $57.514 \%$ of the total variance. Out of this, the highest percentage of variance (28.328) accounts for the first factor, that gathered the group of service offer elements pertaining to certainty of provided service, trust, speed, courtesy, and helpfulness. The second factor, joining $15.190 \%$ of variance, highlights personal attention devoted to guests. The third factor contains quality elements related to precision of provided service. This factor accounts for $13.996 \%$ of variance.

\section{Conclusion}

Research into service quality in terms of consumers' perceptions and attitudes is one of the key activities of any socially responsible and marketing oriented company. Identification and appreciation of consumers' needs and wishes produces a basis for creating their long-term loyalty. Customer care contributes to creating sustainable competitive attitude. Satisfied and loyal consumers, who feel that a given hotel fulfils their demands, are usually willing to stay in it in the future as well, and also recommend it to their friends and acquaintances. This hotel acquires the image of a client-oriented company in the public eye. It is therefore essential for the management to first establish the relevance of different attributes for the customer's choice of a given hotel, and then measure the degree of the guests' satisfaction with the given attributes. 
The results of the conducted study have indicated that, in hospitality and hotel industry, consumers generally tend to attach more importance to intangible attributes. The guests primarily find it important to feel confidence in the hotel's staff, and be sure that no aspect of the provided service will lead to a mistake or misunderstanding. Precision, accuracy, security, speed of service, staff's courtesy and personal attention are service quality elements important to hotel guests. As regards tangible attributes, the guests find it the most important for the hotel to have clean and comfortable rooms, while some additional elements, such as sports facilities, lawns, swimming pools or sauna do not make a decisive impact on their choice of a certain hotel.

The significance of providing client satisfaction is decisive for business performance in hotel industry. Client's satisfaction with hotel offer can be provided with tangible or intangible attributes, but given that the hotel product is indivisible in the client's mind, it must be formed as a compact whole without great difference in quality between its tangible and intangible components. In the context of the conducted research, it is recommendable for the hotel management to employ staff capable of using courtesy and individual approach to clients to reflect an image of the hotel based on feelings of trust and confidence, securing their satisfaction and long-term loyalty. As the research shows that clean and comfortable rooms as a tangible aspect of quality are an important factor in choosing a hotel, the hotel management can provide modern design of rooms and appealing furniture to convey an image of their hotel which directly influences this aspect of customer expectations.

In further research, it would be worthwhile to expand the notion of relevance by considering the guests' satisfaction with various service elements of a certain hotel. In addition, it is possible to establish the impact of various service quality attributes on the client's willingness to visit the hotel again and recommend it. It would also be interesting to compare the attitudes of three-, four- and five-star hotel guests on various attributes. Moreover, a comparative analysis perceptions of guests staying in a hotel for the first time and those who have stayed there several times can also provide useful research findings.

\section{Literature}

AbuKhalifeh, A.N., \& Som, A.P.M. (2012). Service Quality Management in Hotel Industry: A Conceptual Framework for Food and Beverage Departments. International Journal of Business and Management, 7(14), 135-141.

Albayrak, T., Caber, M., \& Aksoy, S. (2010). Relationships of the tangible and intangible elements of tourism products with overall customer satisfaction. International Journal of Trade, Economics and Finance, 1(2), 140-143. 
Marić D. et al.: Analysis of Tangible and Intangible Hotel Service Quality Components

Alzaid, A. A., \& Soliman, A. A. (2002). Service quality in Riyadh's Elite hotels: measurement and evaluation. King Saud University Journal (Administrative Sciences), 14(2), 83-103.

Atkinson, A. (1988). Answering the eternal question: what does the customer want? The Cornell Hotel and Restaurant Administration Quarterly, 29(2), 12-14.

Bebko, C. P. (2000). Service intangibility and its impact on consumer expectations of service quality. Journal of Services Marketing, 14(1), 9-26.

Bettencourt, L. A. (1997). Customer voluntary performance: customers as partners in service delivery. Journal of Retailing, 73(3), 383-406.

Bowen, J. (1990). Development of taxonomy of services to gain strategic marketing insights. Journal of Academy of Marketing Science, 18(1), 43-49.

Choi, T., \& Chu, R. (2000). Level of satisfaction among Asian and Western travellers. International Journal of Quality and Reliability Management, 17(2), 116-131.

Cronin, J. J., \& Taylor, S. A. (1994). SERVPERF versus SERVQUAL: reconciling performance-based and perceptions- minus-expectations measurement of service quality. Journal of Marketing, 58, 125-131.

Dabholkar, P. A., Shepherd, D. C., \& Thorpe, D.I. (2000). A Comprehensive Framework for Service Quality: An Investigation of Critical, Conceptual and Measurement Issues through a Longitudinal Study. Journal of Retailing, 76(2), 139-173.

Daub, C.H. \& Ergenziger, R. (2005). Enabling Sustainable Management through a New Multidisciplinary Concept of Customer Satisfaction, European Journal of Marketing, vol. 39 (9/10), 998-1012.

Getty, J. M., \& Thompson, K. N. (1994). A procedure for scaling perceptions of lodging quality. Journal of Hospitality Research, 18(2), 75-96.

Gronroos, Ch. (2004). Service Management and Marketing: a Customer Relationship Management Approach, John Wiley and Sons Ltd.

Gummesson, E. (2008). Total Relationship Marketing, Butterworth-Heinemann.

Hair, J. F. Jr., Anderson, R.E., Tatham, R.L. \& Black, W.C. (1998). Multivariate Data Analysis. Upper Saddle River, NJ: Prentice-Hall.

Harrington, D., \& Akehurst, G. (2000). An empirical study of service quality implementation. The Services Industry Journal, 20(2), 133-156.

Huang, J., Huang, C., \& Wu, S. (1996). National character and response to unsatisfactory hotel service. International Journal of Management, 15(3), 229243.

Johnston, R. (1995). The zone of tolerance: exploring the relationship between service transactions and satisfaction with the overall service. International Journal of Service Industry Management, 6(2), 46-61.

Juwaheer, T. (2004). Exploring international tourists' perceptions of hotels operations by using a modified SERVQUAL approach-a case study of Mauritius. Managing Service Quality, 14(5), 350-364.

Kandampully, J., \& Suhartanto, D. (2000). Customer loyalty in the hotel industry: the role of customer satisfaction and image. International Journal of Contemporary Hospitality Management, 12(6), 346-51.

Knutson, B., Stevens, P., Wullaert, C., \& Patton, M. (1991). Lodgserv: A service quality index for the lodging industry. Hospitality Research Journal, 14(7), 277-284.

Kotler, P., Armstrong, G. (1994). Principles of Marketing. New York: Prentice Hall.

Kovač-Žnideršić, R., Marić, D., Grubor, A.,\& Salai, S. (2008). Word of mouth and oppinion leadership. Marketing, 39(4), 133-138. 
Marić D. et al.: Analysis of Tangible and Intangible Hotel Service Quality Components

Lockwood, A. J., Jones, P., \& Bowen, A. (2004). UK Hospitality and Tourism SMEs: Differentiation by Size, Location, and Owner Style. Tourism Hospitality Planning \& Development, 1(1), 7-11.

Maričić, B. (2011). Ponašanje potrošača. Belgrade: Publishing Centre of the Faculty of Economics

Marković, S., \&Raspor, S. (2010). Measuring Perceived Service Quality Using SERVQUAL: A Case Study of the Croatian Hotel Industry, Management, 5(3), 195-209.

Milovanović, V. (2014). Total Quality Management as a Profitability Factor in the Hotel Industry, Industry, 42(3), 115-127.

Mola, F. \& Jusoh, J., (2011). Service Quality in Penang Hotels: A Gap Score Analysis. World Applied Sciences Journal (Special Issue of Tourism \& Hospitality), 12, 1924.

Mohsin, A., \& Lockyer, T., (2010). Customer perceptions of service quality in luxury hotels in New Delhi, India: exploratory study. International Journal of Contemporary Hospitality Management, 22(2), 160-173.

Narver, J.C., Slater, S.F., \& Tietje, B. (1998). Creating a market orientation. Journal of Market-Focused Management, 2(3), 241-255.

Oberoi, U., \& Hales, C. (1990). Assessing the quality of the conference hotel service product: Towards an empirically based model, Service Industries Journal, 10(4), 700-721.

Parasuraman, A., Berry, L. L. \& Zeithaml, V. (1985). A conceptual model of service quality and the implications for future research. Journal of Marketing Management, 49, 41-51.

Parasuraman, A., Zeithaml, V. A., \& Berry, L. L. (1988). SERVQUAL: a multiple-item scale for measuring consumer perception of service quality. Journal of Retailing, 64(1), 35-48.

Rivers, M. J., Toh, R. S., \& Alaoui, M. (1991). Frequent-stayer programs: the demographic, behavioural, and attitudinal characteristics of hotel steady sleepers. Journal of Travel Research, 30(2), 41-45.

Shostack, G.L., (1982). How to design a service. European Journal of Marketing, 16(1), 49-63.

Teas, K. R. (1993). Expectations, performance evaluation and consumers' perceptions of quality. Journal of Marketing, 57(4), 18-24.

Urban, G. (2005). Don'tJustRelate-Advocate!: A Blueprint for Profit inthe Era of Customer Power, Wharton School Publishing.

Widing, R., Sheth, J. N., Pulendran, S., Mittal, B., \& Newman, B. I. (2003). Customer Behaviour: Consumer Behaviour and Beyond. Melbourne: Thomson Learning.

Wolak, R., Kalafatis, S., \& Harris, P. (1998). An investigation into four characteristics of services. Journal of Empirical Generalisations in Marketing Science, 3, 22-41.

Wuest, B. E. S., Tas, R. F., \& Emenheiser, D.A. (1996). What do mature travellers perceive as important hotel/motel customer service? Hospitality Research Journal, 20(2), 77-93.

Zaharia, M., Enachescu, D., Balacescu, A. (2014). Evolutions of Employment and Turnover in Services in EU, Industry, 42(2), 21-34. 